\title{
Chapter 8 \\ The Switch from Agency to Causation in Marx
}

\author{
Scott Meikle
}

\begin{abstract}
This paper traces the shift from Marx's labour theory of value to his later forms of value theory and attributes the change to Marx's shift from agency to causation as the dominant dependent relationship in economic phenomena.
\end{abstract}

\subsection{First Edition Versus Second Edition}

From the time of Engels and Kautsky, everyone believed that Marx held only Ricardo's view that exchange value was labour time, known as the Labour Theory of Value (LTV). This began to change in 1972 when Pilling drew attention to the 'forms of value' in chapter one of Capital. ${ }^{1}$ Everyone had known about these, but nobody ever saw anything in them, and Ronald Meek summed things up in his book on the LTV: 'There is no need for us to follow Marx's rather complex analysis of the "elementary", "expanded" and "money" forms of value in any detail'. ${ }^{2}$ But Pilling had inspired others to look again at chapter one, and a non-Ricardian side to Marx's thought started to emerge. Since then there has been disagreement about what this is, but agreement that the second edition of Capital is where it must be found.

But the second edition cannot be trumps. Authors issue second editions for a reason, and if Marx issued his because he had a change of mind we need to know; second thoughts are not always best. Checking Marx's earlier work we find he developed his own theory of exchange value through the Contribution of 1859 , the notes on Bailey, and the first edition of 1867. But he suppressed it and gave the job to Ricardo's theory instead, and the second edition was where he made the switch.

\footnotetext{
${ }^{1}$ G. Pilling, 'The Law of Value in Ricardo and Marx', Economy and Society, 1972, vol. 1, no. 3, 281-307.

${ }^{2}$ Ronald L. Meek, Studies in the Labour Theory of Value, (London, 1973), 173.
}

\footnotetext{
S. Meikle $(\bowtie)$

Research Fellow, Glasgow University, Glasgow, UK

e-mail: scott.meikle@glasgow.ac.uk 
Let us see what that original theory was, and let's call it the 'theory of commodities and money' or TCM for short. ${ }^{3}$

\subsection{The Theory of Commodities and Money (TCM)}

Marx asks two questions in the Contribution: what is the commodity, and what is money? He starts by noting that in the simple relationship of commodities, '20 yards linen = 1 coat', the coat represents the exchange value of the linen. That is Marx's first result: the relationship contains an act of representation. The coat is performing a social office, in representing the linen's exchange value, which is a social property with no natural presence in the world of things, until the coat provides it.

The linen has the same relation to other useful things too, so that:

20 yards linen $=1$ coat, 1 quarter tea, 2 lbs. iron, 1 ell yarn, etc.

Putting these relationships in this horizontal series gives us a sense of the range of the linen's exchange value.

We also see that a thing becomes a commodity when it enters a network of exchangeability relationships with other things. That is Marx's second result: being a commodity is being in a set of social relationships. And his third result is that exchange value is a social property that a thing acquires when it enters such a set of social relationships, and loses when it leaves it.

In that horizontal series, each thing represents the exchange value of the first. But what if only one thing does the representing? Then we would have a vertical arrangement like this:

20 yards linen $=1$ coat

$$
\begin{aligned}
& =1 \text { quarter tea } \\
& =2 \mathrm{lbs} \text { iron, etc }
\end{aligned}
$$

Here only one thing does the representing, and the others are excluded from that job. This is Marx's final result, because this is money.

Marx gives names to the social roles played in ' 20 yards linen $=1$ coat'. The representing role the coat plays he calls 'the equivalent', and the role the linen plays he calls 'the relative'. The role money plays in doing all the representing he calls the 'universal equivalent'. The entire explanation is social: social relationships entered into; social roles performed; functions fulfilled. These things are established in our behaviour, and rest on agreements. Marx makes the point when he says, as he often does, that such and such a function is performed 'with social validity', like gold doing all the representing for instance.

When Marx first asked what money was, he recalled that 'Gladstone, speaking in a Parliamentary debate on Sir Robert Peel's Bank Act of 1844 and 1845, observed

${ }^{3}$ Book I Part 1 of Capital is entitled 'Commodities and Money' so the title 'TCM' fits. 
that even love had not turned more men into fools than meditation upon the nature of money'. ${ }^{4} \mathrm{He}$ adds that you can't get anywhere until you realize that 'the commodity is the origin of money'. And at the heart of the commodity lie those social agreements, and the main one is the coat's act of representation, the equivalent. Samuel Bailey made a lot of the commodity relationship, or 'exchange relation' as he called it, '20 yards linen = 1 coat', yet he never managed to say anything interesting about it because, says Marx, he never asked the crucial question: 'how is it possible to express the value in exchange of $A$ in the value in use of $B$ ?' 5

Formulating the theory obviously depends on the logic of predicates, particularly quality, quantity, and relation, and on the nature-convention distinction. Marx knew the Greeks; had studied Aristotle's Categories; and had a Rhineland education and cultural background. But this sort of thought was vexed in Britain, where logic and metaphysics had been purged as Papist in the seventeenth century, and decried by native philosophers from Hobbes to Hume as 'School Metaphysics'. This cultural loss handicapped British political economists trying to understand the meaning of '20 yards linen $=1$ coat', depriving them of requisite tools.

Marx's kind of social thinking was very unusual for the mid nineteenth century. British intellectual fashion didn't turn towards social things in this way until Wittgenstein in the mid twentieth century, and before then even thought and language were thought of non-socially in individualistic Humean ways. This may be partly why the TCM was so little appreciated. Fashion then looked to the physical sciences. And that was partly why economists were impressed by Ricardo's theory identifying exchange value with a natural quantitative property, viz. time taken making things. It may also be partly why Marx lost confidence in the TCM, or in its favourable reception.

When the coat represents the linen's exchange value, Marx says it 'counts as' the linen's exchange value. But this is a different way of construing '20 yards linen = 1 coat' from Ricardo's way, which says it is an arithmetical equation equating two quantities. This requires finding a property that each side of the equation has. Bailey's objection to Ricardo's theory was precisely that it construes the relation as an equation, and then looks for a property for each side to have equal amounts of, and there isn't one, so they make one up, a hidden one called 'value', to fill the vacancy created by supposing the relation to be an equation in the first place.

Marx likens '20 yards linen $=1$ coat' to an encounter, and he asks what the parties see in each other when they meet? He appeals to the image of kingship, so he obviously thinks some kind of social status lies behind it: 'This man here is only King, because other men behave towards him like subjects. They believe, however, that they are subjects because he is King' (Dragstedt, 24). ${ }^{6}$

\footnotetext{
${ }^{4}$ Karl Marx, A Contribution to the Critique of Political Economy, in Marx and Engels Collected Works, vol. 29, 303.

${ }^{5}$ K. Marx, Theories of Surplus Value, vol. 3, (Progress Publishers, Moscow, 1971), 149.

${ }^{6}$ Page references to the first edition of Capital are to the translation (the first into English) by Albert Dragstedt, in Value: Studies by Marx, New Park, London 1976, hereafter referred to as 'Dragstedt'. Dragstedt translates the original version of chapter one, and the Appendix entitled 'The Form of Value', both of which Marx suppressed in the second edition.
} 
But how does status come into it? Marx suggests that commodity status exists, as other statuses like kingship do, in virtue of agreements conferring what he calls 'social validity'. This applies across social reality as Searle has argued. ${ }^{7}$ Social statuses exist by people agreeing to 'count' something as being something else, and they are often conferred in special procedures, or ceremonies. A church gets the status of a cathedral only if a bishop is appointed to it under proper authority, and similarly for someone 'counting as' a barrister, or some land 'counting as' someone's private property. Searle's formula for it is that over a certain domain $\mathrm{C}, \mathrm{X}$ things count as $\mathrm{Y}$ things, or ' $\mathrm{X}$ counts as $\mathrm{Y}$ in $\mathrm{C}$ '. For example, 'these bits of authorised paper count as legal tender in this country'. But commodity status is unusual, because things acquire it without any procedure. They simply slip into the network of exchangeability relations and acquire the property of exchange value and the capacity to play the roles of equivalent and relative.

Marx continued with this theory into the first edition. The planned chapter six extended the critique of economics by introducing the concept of valorisation to expose how economics builds market features into its supposedly universal account of production. But the chapter was withdrawn. It appears today as the essay 'Results of the Immediate Process of Production' where, in the last few pages, Marx introduces a set of ideas that go dramatically against all his previous work (Penguin, 1044ff). ${ }^{8}$ He moves away from the theory of the commodity, and towards a theory of capital. He drops 'exchange value' and adopts the term 'value'. The surplus, which had been called 'surplus labour', is now called 'surplus value'. He now speaks of labour 'creating value', breaching the distinction between the labour and valorisation processes. 'Valorisation' goes, and 'accumulation' and 'self expansion' arrive. The two 'aspects' of labour appear. Capital becomes an agency with a tendency to expand. The mover is capital, not people, whom capital now makes its instruments. The critique of economics seems to shift towards a radical version of economics.

\subsection{The Combined Theory: TCM \& LTV}

Marx finds himself holding both the TCM and Ricardo's theory at the same time. This means that he has to hold both constructions of ' 20 yards linen $=1$ coat': the construction that says it means that the coat 'counts as' the exchange value of the linen, and the construction that says it means that the coat and the linen contain the same quantity of labour time.

Chapter one in the first edition sets out the TCM. But in the second edition it becomes a complicated attempt to marry parts of the TCM with Ricardo's theory. This is the source of the Byzantine complexities of chapter one that have bothered

\footnotetext{
${ }^{7}$ John R. Searle, The Construction of Social Reality, Allen Lane, London, 1995.

${ }^{8}$ K. Marx, Capital vol. 1, trs. Ben Fowkes, (Penguin, London, 1976), henceforth 'Penguin'.
} 
readers for generations, and of most of the notorious conceptual problems faced by interpreters.

(i) First, the problem of making labours homogeneous. Ricardo's theory logically requires this, because it treats labour as a single quantitative measurable, which presupposes that all its instances are homogeneous and uniform with all others. But labours (or 'activities' in ordinary language) are heterogeneous, belonging to different kinds. The obvious solution is the Utilitarian theory of action, in which there is only one kind of action, and one end that all actions aim at, utility. This has found few supporters except among economists. Marx inherits the problem from Ricardo in the second edition. He didn't face it in the first edition because the TCM does not say that labours are homogeneous, only that labours 'count as' homogeneous (abstract labour) when in the commodity relation.

(ii) Secondly, it gives Marx the transformation problem. In the first edition there is only exchange value. But in the second edition there is also 'value', aka Ricardo's labour time. Marx now has to explain how 'value' is turned into exchange value. And that is the transformation problem, or turning labour time into prices. Generations have sweated blood over this, defending the second edition.

(iii) Thirdly it makes abstract labour a quagmire. In the first edition abstract labour is what different labours 'count as' in commodity relationships. People may work together in a common effort, or privately for themselves. In this case they need to get what others make, and the things they make themselves become means of acquisition, and this is exchange value and things behaving as commodities. When things are exchanged, the labours that made them are still different, but that doesn't matter, because the labours 'count as' being alike. What Marx originally meant by 'abstract labour' is labours 'counting as' being alike, and so being exchange value. But in the second edition, incorporating Ricardo's theory means finding a way to connect labour time (n.b., not labour, but labour time) with exchange value. He adopts the idea that labour 'creates value'. But 'value' is ambiguous between labour time and commodity-hood, so Marx seems to say that labour creates a social status. He can't leave it like that, so he says it is 'an aspect of labour' that makes the value, and another 'aspect' that makes the thing. The first 'aspect' is abstract labour, so abstract labour is no longer an abstraction but a kind of activity with duration in time. ${ }^{9}$ Marx does this sort of thing to the TCM systematically in the second edition to make room for Ricardo.

In the process Marx introduces an ambiguous use of 'value' to mean the labour time embodied in a thing, and also to mean things in their social capacity as commodities, which are now referred to as 'values'. ${ }^{10}$ So the word 'value' now means

\footnotetext{
${ }^{9}$ Paul Sweezy builds his book on the notion of 'abstract labour time'. He writes 'abstract labour is susceptible to measurement in terms of time units', The Theory of Capitalist Development (Oxford University Press, 1942, [1946]), 33.

${ }^{10}$ As in Marx's phrase: 'the equal objectivity of the products of labour as values', Capital vol.1, (Penguin, 164).
} 
both labour time embodied, and the social status of commodity-hood. This ambiguous usage eases Ricardo into the structure of the second edition, and affirms the combined theory. But it also merges a natural property (labour time) with a social status (commodity-hood), and this is commodity fetishism as Marx defines it. He does not want to advertise this, so in the discussion of fetishism in the second edition, he is forced to play down much of the TCM. The parts most affected are the four 'peculiarities of the equivalent form'.

\subsection{The 'Four Peculiarities'}

These are the analytical core of the TCM (Dragstedt, 55-60). The 'first peculiarity' is that it is the coat, the physical thing, and not its exchange value, that acts as representative of the linen's exchange value. But it does this '(note well) . . only within the value relationship ... since no commodity can relate itself to itself as equivalent and thus can also not make its own natural skin into the expression of its own value, therefore it must . . . make the natural skin of another commodity-body into its own value-form' (Dragstedt, 55, original italics). So the coat performs its social capacity in its natural capacity. It is already getting tricky to keep clearly in mind what is social and what is natural. Muddling them is the essence of the fetish of the commodity, and it is insinuating itself from the start.

The 'second peculiarity' is that 'concrete labour becomes the appearance-form of its opposite, abstractly human labour' (Dragstedt, 55). The different kinds of labour are passed around through the exchange of their products, and they all count as bits of one homogeneous uniform or 'abstract' labour, exchange value. But once the social fact of exchange value is established, the new fact comes to have overwhelming importance, and the activity that made the thing pales into insignificance in the face of the social property it counts as being. It is a case of ' $\mathrm{X}$ counts as $\mathrm{Y}$ in $\mathrm{C}$ ', but one in which $\mathrm{Y}$ has become so dominant that $\mathrm{X}$ ceases to signify except insofar as it counts as a bit of $\mathrm{Y}$.

Exchange value appears to exist as thing A, thing B, etc., and this has the effect of mystifying the useful thing, its social property, and the relation between them: 'If I say: Roman Law and German Law are both law, that is obvious. But if I say, on the other hand, the Law, (this abstract entity) realizes itself in Roman Law and German Law, (these concrete laws), then the connection becomes mystical' (Dragstedt, 57). It is all right to say 'this thing counts as a commodity in the market system' (' $\mathrm{X}$ counts as $\mathrm{Y}$ in $\mathrm{C}$ '), but it is a mystification to say 'this thing is a commodity', because it does not make clear that a social status is involved, and even obscures it. This means that economic thought contains a mystification in its conceptual foundation in the notion of the commodity. From his first brush with economic thought, in the Comments on James Mill in 1844, Marx thought it was a distorted and disturbed vision that saturated reality with commerce. In the first edition of Capital, in the 'four peculiarities', he finally showed the deep foundation of it.

The 'fourth peculiarity' is: 'the fetishism of the commodity form is more striking in the equivalent form than in the relative form of value' (Dragstedt, 59). The property of exchange value inheres in things 'only in our traffic with one another' and is 'not derived from nature' as the property of weight is, though it appears natural (loc. 
cit.). Physical analogies like sight involve causal relations between physical things, but commodity-hood is not a physical nature, and commodity relationships are not causal. Marx finds an analogy in the religious world, where things of our own devising give the appearance of being independent of us, and of having a life of their own in which they enter into relationships with us. 'That is the way it is in the commodity world ... [and] this is what I call the fetishism which clings to labour-products as soon as they are produced as commodities, and which is thus inseparable from commodity-production' (Dragstedt, 60).

This particularly affects the equivalent. The exchange value of the 'relative' (the linen) becomes external to it, because the coat represents it. But with the 'equivalent' the natural thing and the social functionary are one and the same, or as Marx puts it, 'the corporeal- or natural-form of a commodity counts immediately as social form, as value-form for another commodity ... it thus appears as a social natural property of a thing' (Dragstedt, 60).

\subsection{Fetishism}

The treatment of the equivalent in the first edition (Dragstedt, 53-60) is an imaginative logical and metaphysical analysis, and a step in explaining exchange value as a social property. It is set out under seven sub-headings. This care is necessary because the problem is delicate, and the prejudices and illusions surrounding the commodity are entrenched and persistent.

The second edition treatment (Penguin, 147-52) is incoherent, lacks detail, explanation, and organization. All the sub-headings have been removed. ' 20 yards of linen = 1 coat', is now called 'the value equation' (147), thus installing the first construction to the exclusion of the second, and Ricardo's LTV over the TCM. The social roles and functions played out in it are given no explanatory weight, and the reader gets no real understanding of the equivalent, or its place in the theory of the commodity. So the commodity and fetishism are not explained. Immediately after mentioning the 'value equation' Marx gets down to Ricardian quantitative considerations of 'the proportion in which the two are exchanged'.

The poor presentation in the second edition has left fetishism out of focus ever since. Even the writer who became the authority on fetishism, Lukács, could not focus it sharply enough to explore it properly. Other authors were even less sure of their footing. Sweezy relies heavily on quotations from Lukács, as if he lacked the confidence to deal with it himself, and even Lukács relies unusually heavily on quotations from Marx. ${ }^{11}$

Commodity fetishism appears, in the first edition, as the fourth of the 'four peculiarities', and is fully integrated into the TCM with the other parts: '20 yards linen = 1 coat'; the social roles things play in these relationships; the network of these relationships that forms the market; and the weird abstractions that this 'commodity world' throws up, such as abstract labour (compared by Marx to the 'abstract animal'). The theory is a coherent whole, which, once stated, illuminates all its parts.

${ }^{11}$ Sweezy, op. cit., $34-40$. 
This is especially true of fetishism, because the notion arises from this theoretical structure, and cannot be described without it, as can be seen in the second edition where Marx tries and fails. Even Lukács could not recover the idea with any precision from the second edition, and without the TCM the best reconstruction he manages is 'reification', which is a poor approximation telling us only that 'a relation between people takes on the character of a thing', with no account of the social role-playing to explain how this is possible and what it means. ${ }^{12}$

Imposing Ricardo's theory forced Marx to consider which bits of the TCM he can mention and which bits he must avoid. Construing ' 20 yards linen $=1$ coat' as an equation means that the commensurability of coat and linen must be accounted for by a common property, and not by the relation of 'counting as' as in the TCM. But it also rules out any serious use of the social roles and functions, because that would imperil Ricardo's account of commodity-hood, which being naturalistic and weaker, is vulnerable in a comparison. However, he cannot explain fetishism without those social roles, so he has to present it as best he can. Hence the problems faced by Lukacs, Rubin, and Sweezy. The loss shows up in many ways. It is often said, for instance, that 'money is a social relation', which invites the economist's stock rejoinder that 'you can't buy anything with a social relation', and without the TCM there is no comeback.

Marx constantly tries to use the results of the TCM without stating the TCM. The analysis of the commodity and its social roles is replaced by vague descriptions and attempts at persuasion. He says, for instance, that the commodity also reflects the social relations of the producers to the sum total of labour as a social relation between objects, a relation which exists apart from and outside the producers. Through this substitution, the products of labour become commodities, sensuous things which are at the same time suprasensible or social (Penguin, 165).

This is not a reasonable summary of the explanation in the first edition. There is nothing explanatory in saying that when things become commodities, 'sensuous things' become 'suprasensible and social'. The TCM explained it with a theory, but here there are only impressionistic descriptions, and the passage is typical.

Lukács thinks fetishism is misperceiving a social relation as a thing, 'reification' as he calls it, but he does not explain. It seems that under capitalism it just happens that 'the relations between men that lie hidden in the immediate commodity relation, as well as the relations between men and the objects that should really gratify their needs, have faded to the point where they can be neither recognized nor even perceived', so that 'the reified mind has come to regard them as the true representation of his societal existence'. ${ }^{13}$

But fetishism is a failure of understanding not of perception. We do not understand that the commodity world is a social construction where things play social roles in a network of social relationships constituting the market. Marx leaves this out of the second edition, so Lukács was trying to recover the concept of fetishism

\footnotetext{
${ }^{12}$ Georg Lukács, History and Class Consciousness: Studies in Marxist Dialectics, trs. Rodney Livingstone, (Merlin Press, London, 1990 (1968)), 83-4. The work was originally published in 1923.

${ }^{13}$ Lukács, op. cit., 93.
} 
from fragments and the rhetorical flourish that material relations between people take on the fantastic form of social relations between things. Marx is forced to play down so much of the TCM that commodity fetishism is left without enough connection to its infrastructure to be intelligible. It is not surprising that for so long readers of Capital should have felt in their bones that fetishism was an important idea, but without feeling confident about where it belonged and what exactly it was.

\subsection{Why Did Marx Impose Ricardo?}

Events in economics may be part of the story. Marx kept up with economics, and attempts to make it resemble physics were growing. Ricardian economists had long hoped 'to ground value in the absolute invariants they thought were provided by physical reality'. ${ }^{14}$ But in Marx's time this ambition was being taken much further. Jevons was explicitly looking to physics to provide an analogy with exchange, and Walras was looking for a Newtonian model for understanding price and markets. ${ }^{15}$ It would be a nice irony if Marx were sacrificing the TCM for some similar pretension. Up until the end of 'Results', Marx's work had been a critique of economics for putting capital at the centre and crediting it with the creative forces that really lie in the cooperative activity of people. Marx's new picture seems to break with that line of criticism, because it too is putting capital at the centre. ${ }^{16}$ After 'Results' Marx has a different aim: he endorses the view of a Russian reviewer that 'The scientific value of such an inquiry lies in the illumination of the special laws that regulate the origin, existence, development and death of a given social organism and its replacement by another, higher one. And in fact this is the value of Marx's book.' (Penguin,102). Over some 20 years there was no suggestion that Marx saw his work in anything like these terms.

Marx loses a lot by the change. He takes on board a lot of conceptual incoherence, such as the idea that labour makes exchange value, and he has somehow to connect exchange value with labour time. By doing things in terms of 'surplus labour' and 'rate of exploitation', as he had before, he gained in transparency over the euphemism and fetishism of economic thought. By switching to 'surplus value' that transparency is lost behind a veil of technicality drawn from economics itself. He also loses the TCM, the social explanation of exchange value, and the theory of commodity fetishism.

Nonetheless, adopting Ricardo had advantages for Marx. He was nervous about not being taken seriously, and being thought a dilettante with strong and eccentric

${ }^{14}$ P. Mirowski, More Heat than Light (Economics as Social Physics, Physics as Nature's Economics), (Cambridge 1989), 188.

${ }^{15}$ Mirowski, ibid., 254-257.

${ }^{16}$ The title of Marx's Contribution of 1859 had been 'A Critique of Political Economy', but by 1867 this was demoted to the sub-title of his new book, beneath the leading title Capital. 
opinions. ${ }^{17}$ Standing on Ricardo gave him locus in the economic debate, and helped make him a player. Furthermore, ditching Ricardo would have contradicted his settled conviction, affirmed in both editions of Capital and in the notes on Bailey, that beneath the list of current prices a realm of hidden quantities 'shines through'. But perhaps the greatest advantage Marx saw is that Ricardo's labour time promised the single measurable quantitative variable needed to realise the Newtonian ambition of unifying all the laws into a single quantitative science of the 'laws of motion' of a market society: the concentration, centralisation, organic composition, and accumulation of capital etc. The ambition was more to do with appearance than substance, because there are no quantities in either edition beside sums of money and physical quantities (ells, tons).

Also, Marx's constant struggle to keep the quantitative side involved, even as he developed the formal theory of commodity-hood, was a perennial albatross (e.g. Dragstedt, 16-20). He evidently concluded that he couldn't have both. Choosing the quantities and Ricardo removed the problem.

Subsequent readers usually thought Capital was economics and Marx an economist. Not all sympathetic readers saw things this way. Orwell saw other things in Marx, and distanced himself from the then prevailing progressive orthodoxy. $\mathrm{He}$ defended Dickens from the charge of being merely a moral critic of society, suggesting that it is not at all certain that a "merely moral criticism of society may not be just as "revolutionary" ... as the politico-economic criticism which is fashionable at this moment'. ${ }^{18}$ But the mainstream opinion was that Marx had laid out the laws of motion of the market system, and some believed this gave socialists a superior ability to predict its future behaviour unavailable to others. It also conceded a lot to the scientific self-image economics had made up for itself in the second half of the nineteenth century. It also did something to absorb Marx further into the modern liberal tradition that had produced economic thought in the first place, which early Marxists were often keen to do.

\subsection{Conclusion}

The most effective weapon in the arsenal of economic thought, today as in Marx's time, is the idea that the commodity and its market forces are things of nature, inescapable parts of the human condition, that they are 'the real world', and that however harsh it may seem sometimes, and however wide the gap between the needs of 'the economy' and the health and wellbeing of those living under it, this is

\footnotetext{
${ }^{17}$ In the Preface to the Contribution he writes: 'This sketch of the course of my studies in the domain of political economy is intended merely to show that my views ... are the outcome of conscientious research carried on over many years.' Marx Engels Collected Works, (Lawrence \& Wishart, London, 1987), vol. 29, 265.

${ }^{18}$ George Orwell, Critical Essays, (Secker \& Warburg, London, 1946), 18.
} 
inescapable reality, and we had better learn to live with it, and stop deluding ourselves with heart-warming stories about being able to do things another way.

Marx's point is that when we find our lives blighted by 'market forces', we are not suffering the effects of natural laws operating; we are suffering the consequences of our own agreements of collective intentionality that constitute the commodity. These agreements have resulted eventually in the full-blown commodity system, the laws and forces of the market, and the trouble caused by the loss of control over our affairs entailed by this is something we have brought on ourselves. Until we come to understand that, and are ready to take control of our affairs back into our own hands, we shall just have to put up with the consequences whatever they are.

Writing in 1946 Orwell reflected that considering 'how things have gone since 1930 or thereabouts, it is not easy to believe in the survival of civilisation', but he did not think this meant abjuring politics. Rather: 'I think one must continue the political struggle, just as a doctor must try to save the life of a patient who is probably going to die. But I do suggest that we shall get nowhere unless we start by recognizing that political behaviour is largely non-rational, that the world is suffering from some kind of mental disease which must be diagnosed before it can be cured'. ${ }^{19}$

This essay is based on a forthcoming book Marx and the Commodity.

${ }^{19}$ The Collected Essays, Journalism and Letters of George Orwell, edd. Sonia Orwell and Ian Angus, Vol. 4, 248-9.

Open Access This chapter is licensed under the terms of the Creative Commons Attribution 4.0 International License (http://creativecommons.org/licenses/by/4.0/), which permits use, sharing, adaptation, distribution and reproduction in any medium or format, as long as you give appropriate credit to the original author(s) and the source, provide a link to the Creative Commons licence and indicate if changes were made.

The images or other third party material in this chapter are included in the chapter's Creative Commons licence, unless indicated otherwise in a credit line to the material. If material is not included in the chapter's Creative Commons licence and your intended use is not permitted by statutory regulation or exceeds the permitted use, you will need to obtain permission directly from the copyright holder.

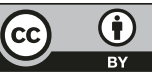

